\section{COFFEE AND SEWAGE.}

To the Editors of THE LANCET.

SIRs,-In The LanceT of Feb. 18th, p. 460, Mr. R. J. Friswell complains of your comment of Feb. 4th on the above as being unfair. In this connexion I should like to point out that, according to Dr. J. W. H. Eyre's examination, each berry acted as a nutritive medium for bacillus coli communis, bacillus enteritidis sporogenes, and sewage streptococci. If the presence of these does not show sewage contamination I should like to know what does. Why is sewage itself dangerous? Because it contains these very organisms and may contain many others more generally recognised as pathogenic. Even were the quantity of sewage small it might be very deleterious because the berries from the way in which they were packed-viz., in bags-acted as a kind of filter bed, freeing the water which passed through them of a large amount both of organic and inorganic filth which became deposited on the surface of the berries. The evidence of the sanitary officials was given on the assumption (uncontradicted) that the coffee during roasting attained a temperature of from $300^{\circ}$ to $400^{\circ}$ Centigrade, but Mr. Friswell in his letter now states this ought to have been Fahrenheit. Had we understood that $180^{\circ} \mathrm{C}$. was the highest temperature we should not have admitted that all organisms were destroyed by roasting, since it is quite conceivable that certain spores may have escaped, not to mention the various cellular toxins. In view of the fact that caffein itself is not destroyed at this temperature I consider it quite an open question whether the products of the various bacteria which infested the berries were rendered harmless.

I am, Sirs, yours faithfully,

R. K. BRown, M.D. R.U.I.

The Town Hall, Spa-road, S.F., Feb. 20th, 1905

\section{HIGH BAROMETRIC PRESSURE AND CEREBRAL HÆMORRHAGE.}

\section{To the Editors of THE LaNCET.}

Sins, - I have only just seen the issue of The LANCET of Jan. 28th in which Dr. James W. Russell of Birmingham has an article on the Relation between Various Atmospheric Conditions and the Occurrence of Cerebral Hæmorrhage. In this he refers to Dr. $R$ Hensleigh Walter as having sug. gested that there is a relation between a high barometric pressure and an attack of cerebral hæmorrhage. Now, so far as I know, I was the first to suggest the influence of a high barometric pressure upon hemorrhages generally, including, of course, cerebral. 'This I did in an article which appeared in 1896," entitled "Hæmorrhages: their Relation to Barometric Pressure." I have drawn cour attention to the above article as in recent literature the fact that the relation between high barometric pressures and hæmorrhages had been observed and commented on nearly ten years ago has been entirely ignored.

I am, Sirs, yours faithfully

Edinburgh, Feb. 18th, 1905 . Thos. WhITELAW, M.D. Edin.

\section{SANTA CRUZ, TENERIFFE, AS A HEALTH RESORT}

To the Editors of THE LANCET.

SIRs,-I wish to draw attention to the claims of Santa Cruz, Teneriffe, as a health resort. I refer more particularly to the new suburbs above the English church (from 200 to 300 feet above sea level), where there are now a rumber of good hotels and pleasant gardens amidst salubrious and picturesque surroundings. The average mean temperature of the winter and spring months is about $65^{\circ} \mathrm{F}$., relative humidity 65 , and rainfall 11.50 inches per annum. There is an abundance of bright sunshine, the nights are warm, and there is a very slight dewfall. There is generally a pleasant breeze from the sea and altogether it may be considered one of the best climates in the world for invalids or people wishing to spend their winters abroal. The electric tramway from Santa Cruz to La Laguna and on to Tacoronte (a rise of nearly 2000 feet) is a great boon to visitors and during the summer Santa Cruz, which is the capital of the Canary
Islands, is a most interesting old city and the most lively in the archipelago. If desired I shall be glad to give any further information.-I am, Sirs, yours faithfully,

Santa Cruz, Teneriffe, Feb. 10th, 1905.

$$
\text { A. W. W. DowDing, M.D. Durh. }
$$

\section{HUNTERIAN ORATORS. To the Editors of THE LANCET.}

SIRS, - It is generally agreed that Mr. J. Tweedy's Hunterian Oration marks a new departure in point of originality and your favourable notice of it will be endorsed by all who heard it. Not only did he offer his audience an unhackneyed appreciation of the work and methorls of John Hunter but he had the courage to analsse one of the tiresome rhetorical commonplaces copied from one another by indolent orators half a century ago, according to which Hunter is likened to Bacon. The orator showed that Francis Bacon, great as he was, was the last of the mediæval philosophers, while John Hunter was a pioneer entirely on a higher plane, because more careful of the truth than the Lord Chancellor who is supposed to have written the plass of Shakespeare. Orators have in the past been cruelly hampered by the necessity of always speaking about the same man. In their de-ire to say something new about John Hunter they have too often unconsciously repeated the veriest platitudes. Sometimes the task has been too much for them. In 1841, for instance, Thomas Callaway failed conspicuously in his oration. He could not decipher his own writing and though more wax candles were brought by Clift, his speech was described as a "most miserable failure." John Flint South in 1844 was original at John Hunter's expense. He omitted to mention him in his oration. Lawrence lost his temper and made a famous attack on the general practitioners who had crowded to hear him (1846). Asked to apologise, be indulged in ferocious repartee and called his audience geese. Luke's oration in 1852 was very poor and Bransby Cooper's "a great failure." The oration of Honoratus Leigh Thomas is described as "a most modest production" in 1827, while Sir Anthony Carlisle simply delivered a lecture on oysters. Hence, his nickname in the pages of THE LANCET ${ }^{1}$ of the time, "Sir Anthony Oyster." Similar in kind though far different in degree was Joseph Henry Green's famous oration on "Mental Dynamics," while in recent years Mr. Macnamara lectured very ably on anthropology and but little on John Hunter. Mr. Tweedy's oration is in some sort a return to the typical exercises in which John Hunter has been kept in view as a text, new and appropriate lessons being drawn from his work and his character. As such it will rank among the classics of the College. I am, Sirs, yours faithfully,

Feb. 20th, 1905 . P. V.

\section{ADVANCED PLUMBING. \\ (FrOM a CORRESPONDENT.)}

Ar examination of the sanitary fittings and plumbc:s' work now nearing completion at the new wing of St. Mary's Hospital, Paddington, is encouraging, indicating as it does that the hitherto slow march of the plumber is being brought into time with the quick-step of modern surgery. At St. Mary's Hospital the greatest attention has been given to every detail and the result reveals a unity of purpose in conception and construction which reflects the greatest credit on all concerned. A special feature throughout all the internal fittings is simplicity in form, there being a complete absence of any attempt at ornamentation. Sharp angles are avoided, all necessary mouldings or projections being rounded or hollowed, thus avoiding corners in which dirt and germs could accumulate. Each part of the several fittings is accessible for cleansing, while all unavoidable jointings are flush. There are several deviations from existing work of the kind that are well worth special attention.

Closts. - The closets are of white enamelled fire clay, on the cantilever principle, carefully formed with roomy shallow pans to avoid fouling, and are fitted with a specially constructed flushing rim that insures thorough cleansing.

1 See The LancrT, Feb. 18th, 1825 : "Hunterian Oration read! by Sir Anthony Oyster .... Iis speech was a fine sample, on the whole, of rhetoric, which the learn'd call ${ }^{\prime}$ "gm irole." 